The French also have an answer to the naive argument that it is impossible to vaccinate against all fiftysix strains of foot and mouth virus and so there is no point in any vaccination at all. They follow continually the epidemiology of the various strains present in Europe and the countries with which they trade, and progressively change to the appropriate strains. No doubt they are now producing vaccine against $A_{22}$, a strain loose in the USSR.

The fact that Holland, Belgium and Germany also have combined vaccination and slaughter policy argues strongly for it. Is it not time for Britain to follow suit ? Even if the Northumberland Committee decides that vaccination of the entire National Herd is not practical, voluntary vaccination and compulsory vaccination to cordon off centres of infection should be used in the future. The folly of prohibiting vaccination while risking infection by importing South American meat ought by now to be apparent to everyone.

Mr Peart should now waste no time in tightening the inadequate inspection control arrangements for imported meat. As a starting point, there is the recent and overdue Argentinian proposal for an exchange of British and Argentinian experts to see what can be done to improve checks for the disease. A three man British veterinary mission will leave for Buenos Aires on March 17. The present arrangements with the Argentine date from the Bledisloe agreement of 1928 and provide only for a visual inspection, by local veterinary officers, of cattle on the farms and at the slaughter and packing plants. Any animal which is either incubating the disease or is a carrier will simply not be detected by visual inspection without quarantine, so there will always be a risk that meat is infected. Furthermore, because of local conditions, a declaration from the farmer is accepted instead of veterinary inspection at the farm. These forty year old arrangements are just not good enough. The disease must be detected before slaughtering by stringent inspection, for it is certainly hopeless to try systematically to check for foot and mouth virus in the bones of refrigerated carcasses.

\section{A Space Policy for Europe?}

\section{by Angela Croome}

The report of the Causse Advisory Committee on Programmes to the European Spacc Conference (ESC) may well set the pattern for European space developments for the next 10 years. After being leaked in Le Monde (March 13) the report was released at the end of the meeting of the Alternates Committee of the European Space Conference (not of ESRO as reported last week) in Paris on March 13-14. The report should be followed by action at the next ministerial meeting of the ESC some time this summer -which will mean that a mere two years have elapsed between the setting up of the ESC and the adoption of a programme. One spokesman for the British aerospace industry remarked that 'it's a great pity that such objectives were not adopted when the two main European space organizations were set up in the early sixties".

The aim of the advisory committee's proposals is a "balanced programme", by which it means a suitable combination of scientific and "useful" satellites and the appropriate means of launching them. "European activity in space should be orientated towards direct objectives, namely, increased knowledge and worthwhile applications. Rather than seek the 'power' objective that has characterized other space policies, Europe should above all demonstrate her determination to be independent. Rather than indulge in illusory competition, she should seek to practise the closest collaboration with the other space powers ..."

The committee was constrained on the one hand by the level of investment that can reasonably be supported by Western Europe, and on the other by the nature of the proposals actually put forward by European groups. These have included candidate projects sponsored by ESRO, ELDO, CETS, Eurospace and Eurovision (the European Broadcasting Union). All these have been assessed by the Technical Sub. committee of five independent experts, after which the economic implications were scrutinized by a larger economic sub-committee representing 13 of the member states of the European Space Conference.

The programme that has evolved allows for three options, one of which should be chosen by the ESC for its immediate target (that is, to come to fruition in the early seventies). The options range from one in which priority is given to an ambitious science programme with the Large Astronomical Satellite as its centre-piece and a minimal applications programme, to one with a fairly comprehensive applications content and a minimal scientific satellite programme (averaging 2 scientific satellites a year, each carrying 8-10 sophisticated experiments). This covers the launching period 1973-76. The Large Astronomical Satellite (LAS) gets rather little attention, and seems to be considered a major technological liability, despite its acknowledged scientific potential. The technical sub-committee believes that it cannot be attempted by adhering to the ESRO budget for its first 8-year period (1964-72) and that it may be outmoded by US activity by the time it is practicable.

The whole programme should be possible if a growth rate of 10 per cent is allowed. The analysis concludes that this is well below $\mathbf{l}$ per cent of the European GNP in the years ahead, assuming an annual growth of 4 per cent. (It is estimated that the US is spending roughly 1 per cent of its GNP on space activity.) The actual figures are equivalent to $\$ 150$ million in 1967 , against a plateau of $\$ 240$ million from about 1972 . For this, a scientific launching programme of two satellites a year, plus the development of a geostationary TV relay satellite for Eurovision use in the $1970 \mathrm{~s}$, is envisaged. There would be enough slack to start on one other type of applications vehicle-navigational, meteorological or earth resource are all of interest. It is pointed out that by dropping LAS, a meteorological satellite can be introduced "giving European meteorologists a chance of taking part in the World Weather Watch in 1973 with a satellite of European construction", and that meteorology incorporates an element of research, so that the sacrifice may not seem so bitter.

A feature of all the options, and a distinct break with the past, is that all the launchings employ the 
European launcher based on the British Blue Streak. The adoption of ELDO launchers for the scientific payloads as well as for the applications satellites will put launcher production on a rational basis (an average requirement of four a year). The report points out: "... the present situation is indeed unsatisfactory ... the programme as a whole is neither coherent nor balanced. It does not include any applications satellites ... and the launcher projects are mainly justified by applications satellite projects." It also calls for a sustained development programme for the ELDO vehicle, involving strap-on boosters, liquid hydrogen upper stages and possibly electric propulsion, for the tasks of the later seventies. The possible ELDO-4 launcher, for instance, would have about double the capacity of the present ELDO-1 specification and could place 2 tons in geostationary orbit, enabling direct-broadcast colour television to be supplied to all of Europe as well as Africa and the Middle East by 1978. Blue Streak is seen as perfectly suitable for the booster stage throughout the period.

A number of decisions are called for by the report, but, the authors point out, four of them are urgent and must be taken by the ministers this year-the future of the LAS, a start on the Eurovision satellite, increase in production of ELDO launchers and statutory bodies to handle the problems of organization. But what is needed most is a firm decision to pay. ESRO has been living from hand to mouth for two years now.

\section{CERN Meeting}

THE 37th meeting of the Council of CERN, held last week in Geneva, discussed the progress being made towards the building of the $300 \mathrm{GeV}$ accelerator. Most of the progress is at the organizational level, but it now seems clear that a final decision on the project should emerge by the end of this year, probably in December. There were also hopeful signs for supporters of the machine that fewer governments are dragging their heels than was the case at the end of last vear. The United Kingdom delegation, in particular, expressed itself completely satisfied with the answers given on design, cost, management and collaboration, and said that there was now no reason why these issues should be reopened. The German delegation was rather more subdued, for reasons of its own, but put forward no major objection.

It is now also clear that a decision about the siting of the laboratory should be made in the summer of this year, and a short list of four sites should be ready by June. At the moment, nine sites are still under consideration, and technical reports have now been published on each one. They are Aspropyrgos in Greece, Doberdo in Italy, Drensteinfurt in Germany, El Escorial in Spain, Focant in Belgium, Gopfritz in Austria, Le Luc in France, Mundford in the United Kingdom and Uppsala in Sweden. The final decision will be taken in two stages; a preliminary vote will be used to reduce the number of sites to four, and the delegates last week agreed that this vote should be taken in open ballot, though it is possible that it could be done in closed session. But, whatever the choice is to be, it will have to await promises of money which represent a substantial proportion of the cost of the accelerator. In other words, countries will have to commit themselves to the project before they know where it is to be built.
At the organizational level, the delegates agreed to the formation of a steering committee to work on the $300 \mathrm{GeV}$ project until an advisory committee for the project is formed. The function of the advisory committee would be to assist the director-general of the new laboratory, and it might also exercise some form of control. As a stopgap arrangement, the steering committee has been set up to fulfil this function; the membership is Professors Amaldi and Amman of Italy, Dr J. B. Adams and Professor Merrison of the UK, Dr Levy-Mandel of France, Professor Paul of Germany, and Drs Hine and Zilverschoon of CERN; the director-general of CERN is an ex-officio member. Several delegates emphasized the need for speed, particularly once the decision to go ahead has been taken. Professor Puppi of the Science Policy Committee, for instance, said that the name of a proposed director-general could be put forward very quickly. The feeling seems to be that the second the decision is taken, the delegates should dash from the meeting to lay the foundation stone, before anybody can change their minds.

\section{Engineers of the World Unite}

National engineering organizations from all over the world got together recently under the auspices of Unesco to form a World Federation of Engineering Institutions. At a meeting in Paris from March 4 to 7 , representatives from 60 countries and four regional organizations gave sanction to a plan to set up the federation. The hope is that it will do for engineering what the International Council of Scientific Unions does for science - a process of organization, co-operation and, to a limited extent, unification.

The World Federation will replace or supplement a number of other international bodies which for reasons of representation or organization were unable to do the job. There have been limited groupings of national institutions for a number of years - there was one in Europe, one for the Commonwealth, and another covering the Americas. These organizations will no doubt co-exist with the new one quite happily. The only organization whose continued existence is threatened is the Union des Associations Techniques Internationales, based in Paris, which has for some time been regarded as something of a lame duck. Uneseo has been pressing for a new organization for some years, and it seems that its gentle prompting met with a ready response from the national engineering institutions. At the Paris conference the federation was set up by a unanimous vote.

The first president of the federation will be the Swiss engineer Dr Eric Choisy, and Mr R. Gibrat of France will be vice-president. It seems likely that much of the executive work of the federation will be done at the Institution of Electrical Engineers in London-the secretary of the institution, Dr G. F. Gainsborough, has been appointed first secretarygeneral of the federation. The federation itself will consist of national members, which will be the representative engineering body for each country (in Britain the Council of Engineering Institutions), and some international members, representing existing federations throughout the world.

Dr Gainsborough is enthusiastic about his new responsibilities. Already, he says, two projects have been started. The first is to set up a committee to 